PART 2

Development Outcomes and External Influences 
Fernando Eguren - 9789004351677

Downloaded from Brill.comఠ4/26/2023 02:56: $88 \mathrm{PM}$ via free access 


\title{
Socialism in the Twenty-First Century and Neo-liberalism: Diverse Ideological Options Do Not Always Generate Different Effects
}

\author{
Fernando Eguren
}

\begin{abstract}
This chapter seeks to demonstrate that policies derived from different ideological options do not necessarily generate significantly different effects. In the Andean region, the governments of Rafael Correa, in Ecuador, and Evo Morales, in Bolivia, have been following a political line of 'twenty-first century socialism', while the governments of Colombia and Peru have directed their political orientations towards neo-liberalism and the 'Washington Consensus'. Nevertheless, two issues of importance-namely, the handling of the processes involved in the concentration of property land rights and the treatment of indigenous populations - demonstrate that the actions of these two groups of countries have not led to very different results. The fact that these countries have become part of the globalisation process has permitted variations in the relative radicalism of the governments' political discourses but has led to significantly less flexibility with regard to the degree of autonomy that these governments face for implementing policies. Additionally, domestic social conflicts have set limits on the states' abilities to manoeuvre when implementing their policies.
\end{abstract}

In the last two decades of the twentieth century, several countries in the Latin American region adopted structural adjustment policies to tackle certain grave economic problems caused by high debt levels, which were in turn the result of easy access to loans due to the abundant liquidity brought about by high oil prices. A subsequent increase in interest rates meant that the aforementioned debts were basically unpayable. In many cases, these loans were used to finance fiscal debt. The financial institutions that oversee debt levels, particularly the International Monetary Fund and the World Bank, imposed rigid conditions and controls on national economies to secure debt payments. These events contributed to putting an end to a period, which began in the middle of 
the last century, during which governments directed their economic strategies, with varying degrees of conviction, at strengthening internal markets, developing manufacturing and substituting imports.

During the same period, globalisation forged closer links between national economies and international markets. The degree of intensity and speed with which these ties were established depended on the orientation of each government in terms of economic policy, which was in turn influenced by ideological options, by the strength of each state's institutions, by each government's sensitivity to social and environmental problems, and by the greater or lesser degree of social and political participation exercised by countries' respective civil societies.

These differences had a significant impact on the relations between the state and the market, on public and private institutions, on political and social organisations, and on the socio-economic structure of countries, while affecting the concentration or distribution of economic and political power. They were also expressed in leaders' political discourses, which may reflect or hide the real results of their respective policies, whether these results are desired or undesired, intentional or unforeseeable.

But none of this could neutralise the immense influence that globalisation was having on national economies and on the limits that this influence imposes on the autonomy and sovereignty of states. Thus, it should not be surprising that governments that differ in their ideological and economic tendencies eventually opt, in terms of issues that are structural and of great importance, for similar policies and results despite divergent discourses and intentions. This does not necessarily mean that leaders behave in ways that are inconsequential. Instead, it may actually reflect their lack of capacity to transform dimensions of reality that are driven by relations and dynamics that are beyond the influence of state intervention.

This brief essay compares the impact of this situation on important aspects of agricultural and rural issues in four Andean countries: Bolivia, Colombia, Ecuador and Peru. Two of these nations (Bolivia and Ecuador) adopted, after a succession of neo-liberal governments, 'twenty-first century socialism', a political ideology disseminated by the President of Venezuela, Hugo Chavez, ${ }^{1}$ while the other two nations (Colombia and Peru) continued to apply the neo-liberal policies that were introduced in the 1980 os and inspired by the 'Washington Consensus'.

1 The bases of this conception of socialism are, in simplified form, developmentalism, participative democracy, the central role of base organisations and the reduction of inequalities. 
The first section of this chapter describes, in summary form, the precursors that eventually led the countries in question to align with one option or the other. The second section attempts to shed light on the impact that this alignment had on one of the most important components of agriculture: the concentration of land rights. The third section focuses on the particularities of the treatment of indigenous issues. The final section provides the chapter's main conclusions.

\section{$2 \quad$ Background}

In this section, we will discuss the processes that led the four countries to opt for either twenty-first century socialism or neo-liberalism. The starting point was the economic crisis that was unleashed by the excessively high external debt load that governments assumed in the 1970s and 1980s.

The way the Bolivian economic crisis was faced in the first few years of the 1980 s did not escape the vicious circle 'inflation-package-of-measuresinflation', the positive effects of which were short lived. Morales $(2008,2)$, in his analysis of the Bolivian case, sets the beginning of the crisis during the tenure of Hernan Siles Suazo's government (1982-85), who was elected following a succession of military dictatorships. Bolivia suffered hyperinflation, which multiplied prices by 625 times between April 1984 and August 1985 in the midst of serious social uprisings and with a government that had limited capacity to control them (Morales, 2008). Victor Paz Estenssoro succeeded Siles Suazo and inaugurated a long period of neo-liberal policies, which quickly put the brakes on hyperinflation but also generated highly negative effects for the population. Social conflicts became highly intense at the beginning of the new century and submerged the country in an acute political crisis that lasted until the election of Evo Morales in 2005.

President Evo Morales drove a significant shift in economic policy. He forced a review of contracts with foreign extractive companies, particularly in the hydrocarbon sector, which increased fiscal revenues in a context marked by price increases in the international market for raw materials. This additional revenue facilitated the application of distributive policies that increased Morales's popularity. But just as importantly, perhaps even more importantly, he prioritised indigenous issues in his political discourse, a fact that has undoubtedly empowered these groups. This recognition was embodied in the new constitution approved in 2009. The first article of this document defines the 'Unitary Pluri-National State', while the second recognises the 'free determination' of indigenous peoples, which consists of 'their right to autonomy, 
self-governance, their culture, recognition of their institutions and consolidation of their territorial bodies'. In a country in which 42 per cent of citizens are recognised as indigenous (census of 2012), it is not surprising that Morales has been re-elected twice by large margins.

Like Bolivia, Ecuador also experienced various governments that applied neo-liberal policies prior to Rafael Correa's election as president in 2006. These policies were initially adopted by President Osvaldo Hurtado (1981-84) and his team. One of the primary objectives at this point in time was to pay both public and private external debt (Acosta, 2006, 168). Subsequent governments-led by Leon Febres-Cordero (1984-88) and Rodrigo Borja (1988-92) — followed the same path, which was consistent with their conviction that, in the words of Alberto Acosta, 'the achievement of macroeconomic balance... [became] almost a substitute for economic and social development, which should have been subsequently achieved, practically spontaneously, according to neoliberal arguments, as a product of stabilisation' (Acosta, 2006, 178, our transl.). It was during this period that, at the behest of the World Bank, the government implemented targeted social service programmes as compensation initiatives to favour the sectors of the population that were most affected by neo-liberal policies, policies that were also being applied in other countries in the region. During these years, the results of the application of neo-liberal policies could not have been more discouraging: from 1980 to 1989 , the annual growth rate in Ecuador was -0.7 per cent (Acosta, 2006, 180). Subsequent governments fared no better. In 1999, Ecuador experienced its most severe economic recession and posted the fastest pace of impoverishment in Latin America (Acosta 2006: 196). These ongoing economic problems were accompanied by political and social upheaval: in just seven years-from 1996 to 2003-five different presidents took office.

It is not surprising that the citizens of Ecuador, after more than two decades of their country being poorly managed, were willing to elect someone who offered to break away from previous policies. In this context, Rafael Correa took office at the beginning of 2007 in alliance with leftist parties and indigenous organisations. Correa introduced major changes that led to his re-election on two occasions, in 2009 and 2013.

The direction that the new Ecuadorian government would take was inscribed in the new constitution approved in 2008. This document strengthened the role of the state in the economy; addressed ideas of increased equality, redistribution and economic and social rights in several articles; recognised the pluricultural and multi-ethnic nature of Ecuadorian society; institutionalised citizens' roles in the management of public issues; and strengthened the central state as well as the local and cantonal governments. 
The ascent of Morales and Correa to office was preceded by a series of similar events in each country: recognition of the fact that neo-liberal policies had failed to end the economic crisis, and citizens' demands for a change in direction.

Colombia also experienced a long period of economic crisis due to the external debt assumed between the mid-1970s and the mid-1980s. The government found it difficult to make timely debt payments and, in 1973, implemented fiscal policies to balance the budget and establish strict monetary order (Parada Corrales and Baca Mejia, 2009, 19). Ten years later, in 1983, during the presidency of Belisario Betancur, the government instituted adjustments and made macroeconomic policy more open in order to correct the exchange rate lag, reduce the current account deficit in the balance of payments, cut the fiscal deficit and put the brakes on the inflationary spiral (Pineda Hoyos, 1996). Under President Virgilio Barco, this programme for economic openness in Colombia was expanded, and this expansion was even more marked during the term of his successor, Cesar Gaviria (1990-94). During his administration a new constitution was approved, which consecrated democratic principles and opted for an economy of openness to the market and foreign investment. Throughout the 1990s, Colombian macroeconomic policy remained aligned with the prescriptions of the Washington Consensus (Parada Corrales and Baca Mejia, 2009, 22). The government of President Uribe, which lasted eight years (2002-10), inherited a critical economic situation-for some the worst economic crisis in the country's history-which was reversed thanks in large part to major foreign investments, particularly in extractive, hydrocarbon and mineral activities. Nonetheless, this failed to reduce high rates of unemployment and social inequalities (Dinero, 2010). President Santos, elected in 2010, continued to apply the economic policies pursued by previous governments. Why did a socialist option not emerge despite the limited success of neo-liberal policies? For many, the Left was the main culprit in the protracted and cruel civil war that was racking the country, and thus voters were not willing to elect a Left-leaning government.

In Peru, agricultural reforms were the most important of the deep reforms led by the military government of the 1970s. These were financed to a large extent with external debt. In the second half of the decade, the debt figure became sufficiently problematic to warrant periodic adjustments, which were ineffective. In the 1980s, the return to democracy began. A series of prior reforms were rolled back and the economic crisis worsened. The country's political instability, which became manifest in the last few years of over a decade of military government, worsened with the appearance of the terrorist group known as the Shining Path, which initiated actions in poor rural areas populated 
primarily by peasants. Under the government of Alan Garcia (1985-1990), the political and economic crisis reached levels that had no precedent in the twentieth century, due to an incompetent approach to economic policy management and the advance of the Shining Path.

The economic shock administered in the early days of Alberto Fujimori's rise to power (1990-95 and 1995-2000) ${ }^{2}$ marked the beginning of a long period of neo-liberal economic orientation. During most of the first decade of the new millennium, and the few years that followed, the country posted the highest growth in its history as a republic. This was driven by high mineral prices and huge foreign investments in extractive industries. Ollanta Humala was elected president in 2011 on a moderately Leftist platform, but once in power his government decided to continue the economic direction set by previous governments, which had reaped good results in terms of gross domestic product (GDP) growth.

\section{Concentration of Property Rights to Agricultural Lands}

To what extent did the different orientations of these four countries' governments - on one hand, those of Ecuador and Bolivia and, on the other, those of Colombia and Peru-have an impact on the most relevant problem in the realm of agriculture: property rights?

In 2012, the regional office of the Food and Agriculture Organization of the United Nations (FAO) for Latin America and the Caribbean published the results of a study conducted in 17 countries in the region that aimed to discover if processes of concentrating property rights were in play and, if this were the case, to determine the modalities of these processes (Soto Baquero and Gómez, 2012). This study was spurred by concerns about the extent to which the region had been affected by the phenomenon of land grabbing, particularly prevalent in countries of Africa and Asia, which had captured the world's attention at the end of the first decade of the twenty-first century.

The case studies commissioned by FAO gave rise to a series of reflections that were later systematised and disseminated (Soto Baquero and Gomez, 2014). Some general considerations are pertinent to this essay given that the cases include Andean countries. These studies demonstrated that the concentration of agricultural land among foreign investors, and transfers of land property to

2 In a single day the currency was devalued by more than $200 \%$, the price of gasoline was increased by $3,000 \%$ and all subsidies for public goods and services were eliminated and their prices were released. 
foreign investors, had risen to significant levels in the region despite the fact that respective governments held different policy positions. But, unlike the situation in Africa and Asia, the largest purchasers of lands in Latin American were national or trans-Latinas (regional transnational) investors. The studies also show that concentration was particularly prevalent in export segments, particularly for soybean products and other grains, biofuels, traditional export products (bananas, coffee and tropical fruits), non-traditional products (fruit and vegetables) and forest products. Another feature of these processes was the fact that they set up strong value chains, which included monitoring both the inputs and production, and the sale and distribution of products, which left the door open to monopolistic practices.

In Bolivia, beginning in the middle of the last century, the government encouraged the occupation of lands in the eastern department of Santa Cruz, giving rise to latifundia (large landholdings) that were not affected by the agricultural reform of 1953. This led to the development of modern capitalistic agriculture in the eastern part of the country after it was decided that 'foreigners will have the same rights as Bolivians to no-cost lands provided by the State' (Urioste, 2012, 63). Between 1953 and 1992, 402 people received 7.7 million hectares from the Bolivian state through the National Council for Agricultural Reform.

By the end of the last century, the department of Santa Cruz had become a major producer and exporter of soybean. Over one million hectares were dedicated to this crop. The department was also the target of major investment in the tertiary sector linked to natural gas exploitation and export. Between 1990 and 2007, the cultivated area of the department of Santa Cruz increased from 413 thousand hectares to 1,822 thousand hectares, which constituted two-thirds of the total available cultivated hectares in the country (Urioste, 2012, 71). The subsequent incorporation of new farmland has consolidated a tenure structure polarised between large and small farming.

Thus, Santa Cruz became the country's most important department in terms of agricultural production and the principal driver of the national economy (UNDP, 2004, 36-37).

The concentration process in Bolivia was characterised by a particularity: it was driven, to a great extent, by Brazilian agricultural investments in the department of Santa Cruz. La Fundación Tierra estimated that in 2010 around 40 per cent of the soybean business was in Brazilian hands, while the Mennonites - who had begun migrating to Bolivia in the 1950s-possessed 20.2 per cent and domestic businesses held 28 per cent (Bolivia Rural, 2010).

Urioste $(2012,64-5)$ provides us with a summary of the evolution of land legislation. In 1996, the government of Sanchez de Lozada passed the National 
Agrarian Reform Service Law, known as Ley INRA, which stipulated differentiated treatment for lands that were purchased by agricultural businesses, which could be transferred through purchase or sale, and land held by indigenous peoples and small businesses, which was protected by the state and excluded from the land market. The same law set a ten-year limit for regularising the situation of all the country's land. When the ten-year period came to its end whereas the objectives set by the law had not been reached yet, the government of Evo Morales passed a new law - the Communitarian Reorganisation of the Agrarian Reform Law (Reconducción Comunitaria de la Reforma Agraria), which expanded the power of the executive to provide territorial titles in favour of indigenous populations and return lands from unproductive latifundia. During the tenure of his first government, Morales issued titles for 16 million hectares; around two thirds of these lands were awarded to indigenous peoples and peasant communities as collective property, the majority of which were located in the east and in the Amazon. But the distribution of individual lands to peasants has been very limited and the latifundia have not been eliminated. Little progress has been made in regularising lands held by medium- and small-scale businessmen in the eastern region due to potential conflicts given that a significant portion of these lands were acquired illegally. Agribusinesses and livestock farmers in the east, who radically opposed Morales' government during its initial years, led political negotiations to achieve a temporary truce that continues to this day. Moreover, the political constitution approved in 2009 establishes limits on the size of property holdings - in theory, five thousand hectares-but a trading company can multiply this number by the number of its shareholders (article 315), which allows such companies to set up latifundia. The constitution also stipulates that 'foreigners [...] cannot acquire State land under any title' (art. 396, inc. II) but private or natural persons and companies may do so. As a matter of fact, it is common for Bolivians to acquire state-owned land and to later transfer it to foreign investors. In sum, the concentration of arable land in Bolivia has not changed.

The case was similar in Ecuador. The country passed legislation for agricultural reform but there was little enforcement and, as such, the impact on large property holdings was not significant. Traditional haciendas, which characterised the structure of agricultural lands until the seventies, were being 'metamorphosed' through a process in which the rentier model for land use was abandoned and replaced by agribusiness (Martinez Valle, 2014, 127).

Similar to the situation in other Andean countries, Ecuador also has significant land concentration, but in this case associated with exports of traditional products (bananas and sugar), which differs from Bolivia (soybean) and Peru (vegetables and fruit). Recently, the tie with the external market for 
biofuels - which an increasing number of sugar and palm oil plantations seek to produce-has strengthened; by comparison, the ratio of concentration is lower in areas that produce crops destined for internal markets, as is the case in other countries in the region (Martinez Valle, 2012, 231).

The constitution of 2008, which was approved under Correa administration, explicitly prohibits latifundia and the concentration of landholdings (art. 282). Thus, some political rhetoric criticises concentration but no concrete measures have been applied to limit this practice, and even less effort has been dedicated to adopting some kind of agricultural reform. This despite the fact that the Organic Law of the Food Sovereignty Regime of 2009 contemplates restrictions on land grabbing but postponed the implementation to a future law 'that will establish procedures to eliminate this practice and to determine the mechanisms to ensure that [the land's] social and environmental objectives are fulfilled' (art. 6). In practice, efforts have been limited to forming a land fund that is controlled by the state; the fund has an undetermined area that encompasses from 120 thousand to 300 thousand hectares to be transferred to peasants under an associative format.

Martinez Valle underlines the contradictions of the government's agriculture policy. On one hand, the legal framework contemplates a high level of social content, such as the above-mentioned Organic Law of the Food Sovereignty Regime, and gives preference to small farming interests; yet on the other hand, other policies contribute to consolidating agribusinesses.

Efforts to promote 'inclusive businesses', which supposedly seek to benefit small farmers by linking them to agribusinesses, are actually a veiled form of land grabbing that condemns the small farmer to permanent self-exploitation. Furthermore, by driving a programme of biofuel support, the government consolidates the very crops that are associated with land concentration (Martinez Valle, 2014, 150-151).

At the end of 2015, a legislative debate turned to a new proposal for a law known as the 'Rural Land and Ancestral Territories Law'. According to its critics, including the Confederation of Indigenous Nationalities of Ecuador (Confederación de Nacionalidades Indígenas del Ecuador: CONAIE), the law favours agribusiness and does not contemplate structural issues such as defining limits for latifundia and land concentration. ${ }^{3}$

3 Source: Sistema de Investigación sobre la Problemática Agraria en el Ecuador (SIPAE), Corporación de Gestión y Derecho Ambiental (Ecolex), Fondo Ecuatoriano Populorum Progressio (FEPP), Monitoreo Agrario (6/12/2015), URL: http://www.monitoreodelatierra.com (accessed on 11 November 2016). 
Agricultural reform laws passed in Colombia in 1961, 1968, 1973 and 1980 also failed to modify the country's highly unequal agricultural structure. Additionally, the violence that reigned in the countryside led to a higher concentration of land in the hands of drug cartels or armed groups. In the best of cases, marginal agricultural reform was implemented, which resulted in no changes in the landholding structure and limited its scope to titling fallow land areas (Salinas Abdala, 2012, 181).

Land issues in Colombia cannot be understood or explained without reference to the violence that has consumed the country for decades. The lands of hundreds of thousands of peasants have been seized by armed groups linked to drug trafficking to build latifundia, the proceeds from which have, over time, been 'laundered'. By 2014, the rural population that had been displaced totalled 5.8 million. These individuals had been forced to abandon 6.6 million hectares, equivalent to 12 per cent of the country's farmland (Amaya et al., 2015, 34). The drivers of the agriculture sector are closely tied to the system of landholding and that for compensating victims of conflicts in rural areas (OECD, 2015, 6); both these issues have been centre stage in the successful negotiations between the Colombian government and the Revolutionary Armed Forces of Colombia (FARC).

The Colombian government's policy over the last decade has contributed to consolidating social and economic inequality. In the 1990s, and at the beginning of the new century, various programmes for small-scale agriculture were dismantled. The state's capacity for defining and executing policies to steer agricultural development in a more equitable direction was also weakened. The private sector has assumed the role of directing agricultural development (UNDP, 2011, 42), but in a way that benefits large producers thanks to direct subsidies and transfers (OECD, 2015, 13). The degree of inequality of land distribution in Colombia is one of the highest in the world (UNDP, 2011: 198). According to the Colombian Institute for Rural Development (Instituto Colombiano de Desarrollo Rural: INCODER ), 52 per cent of the country's land belongs to 1.5 per cent of owners while 78 per cent of farmers are minifundistas (very small landholders) (Amaya Navas et al., 2015, 24). The highest concentration of property is evident in the areas most affected by population displacement and those located near extractive investments, which has further complicated conflicts over land use (Salinas Abdala, 2012, 186).

According to UNDP, the rural development model in Colombia fails to promote human development and makes the rural population more vulnerable. It is viewed as unequal and unfavourable to the convergence of rural and urban spaces in terms of socioeconomic development, and is believed to hide gender differences, discriminating against women. The model is considered to be 
exclusionary and is seen as failing to promote sustainability; it is also thought to favour the concentration of rural property and to contribute to the conditions that drive conflict. In short, the model is basically undemocratic and fails to strengthen institutions at the rural level (UNDP, 2011, 34).

Unlike Ecuador and Colombia, Peru executed one of the most radical agriculture reforms in Latin America in the period 1969-75. The reform was led by the military government presided by General Juan Velasco Alvarado. All latifundia, whether modern or traditional, were expropriated. The landholding class was erased from the map. Many resituated to other economic sectors, some emigrated and others suffered a radical change to their household income and social status.

The expropriated haciendas were transformed into agriculture cooperatives, which maintained their original dimensions. But the cooperatives' economic and organisational failings led their members-who before worked on the haciendas - to liquidate holdings and distribute the land and other assets among families. Family agriculture dominated the rural space until Alberto Fujimori took office in 1990. A few months into his first term, Fujimori administered a radical economic shock as the first step towards adopting an openly neo-liberal policy. The constitution of 1993 and the subsequent reforms reduced the protection of lands held by peasant communities, facilitated the inclusion of these holdings in the land market, and set the bases upon which to eliminate all of the restrictions on property that had been in effect since 1969 (Eguren, 2004).

In just a few years, dozens of large companies were formed. The vast majority were dedicated to exporting fruit and vegetables. Around one-third of the arable land along the coast, which is the most fertile and best positioned for irrigation, belongs to fifty companies that hold more than one thousand hectares each. The value of agricultural exports grew eightfold in ten years, rising from USD 621 million in 1995 to USD 5,078 million in 2014 (Central Reserve Bank of Peru, 2016). State support for large agro-industry exporters was-and continues to be-conspicuous. These companies benefit from preferential income tax rate ( 15 per cent instead of the 30 per cent income tax rate to which non agro-industrial firms are subjected) and benefit from a labour regime that 'increases the flexibility' of mechanisms for hiring and firing wage-earning employees in order to reduce labour costs.

In Peru, many 'neo-latifundia' have been formed on state-owned lands, which is common feature to all Andean countries. These lands were carved out of the desert thanks to large and costly irrigation works that were financed with public resources. It is estimated that in the last two decades, the state has invested USD 6,321 million, 93 per cent of which was in the form of net 
subsidies to the buyers of this new land. These buyers were, in every case, agroindustry exporters (Eguren, 2014). Since the 1990s, all administrations have maintained the same policy; without decisive and persistent government support, this phenomenon of concentration would not have occurred. The majority of the investments involve domestic capitalists despite the fact that there are no restrictions on foreign investment.

In addition, other elements have led to the concentration of land. These include the transfer of the large agro-industrial sugar cooperatives to private investors; the sale of unproductive state-owned land at rock-bottom prices; and, finally, land concessions for sugar cane and palm oil plantations for biofuels (Eguren, 2014, 178).

Four decades after the aforementioned radical agricultural reform, a bipolar agricultural system has once again taken shape on the coast, with a few owners holding a lot of land while small farmers have too little.

Two external factors have strongly influenced the fact that Andean countries have maintained, and even intensified, their concentration of landholdings. First, the increase in global demand for agricultural products, and second, the changes that have occurred in market structures, which have attracted large investments to countries with neo-liberal policies and to those with more nationalist and protectionist discourses.

A characteristic that defines the rural societies of the Andean region is the existence of a large indigenous rural population that maintain their own longstanding institutions, customs and behaviours, many of which are secular. Peasant or indigenous communities have communal landholdings, particularly in the Andean highlands, or exercise control over vast territories, which is the case of native populations of the Amazon. These lands are also important identity references for populations that are generally marginalised by society at large.

In the last few decades, important progress has been made in recognising indigenous populations and their rights. Perhaps the most important effort in this regard was Convention 169 of the International Labour Organization (ILO) on indigenous and tribal peoples, which was binding for dozens of states, including all the four Andean countries studied in this chapter. ${ }^{4}$ In general, and

4 Indigenous and Tribal Peoples Convention, 1989 (No. 169). Spanish-language text: http://www .ilo.org/dyn/normlex/en/f?p=NORMLEXPUB:12100:0::NO::P1210o_INSTRUMENT_ID,P12100 _LANG_CODE:312314,es (accessed on 11 November 2016). 
TABLE 6.1 Indigenous populations in four Andean countries

\begin{tabular}{lll}
\hline Country & Indigenous population & $\begin{array}{c}\text { \% of the indigenous } \\
\text { population / total }\end{array}$ \\
\hline Bolivia (2012) & $4,032,014$ & 40.2 \\
Colombia & $1,559,852$ & 3.4 \\
Ecuador & $1,018,176$ & 7 \\
Peru & $7,021,271$ & 24 \\
\hline
\end{tabular}

SOURCES: FOR BOLIVIA, NATIONAL INSTITUTE FOR STATISTICS OF BOLIVIA (2013). FOR THE OTHER COUNTRIES, CEPAL (2014a, 43).

beyond differences of political orientation, all countries in Latin America have made progress towards recognising these populations, including 'expanding the powers of autonomous institutions and transferring responsibilities from the central levels of States to said institutions' (CEPAL, 2014a, 20).

Indigenous populations' weight in the total populations of Andean countries varies significantly, as is shown in Table 6.1. Further, the criteria used to define an 'indigenous population' varies from country to country and also depends on the type of information that is available. Basically, there are two ways of defining indigenous: as determined by an external agent based on ad hoc criteria (for political purposes, to 'instrumentalise' specific programmes, or to determine which sectors of the population can have access to benefits and which will have no access) or by self-perception, as is the case of censuses that record information on ethnic belonging as determined by the person registered; the latter is the case for Bolivia. ${ }^{5}$

Bolivia is, without a doubt, the country that has elevated indigenous issues to higher official spheres. The revaluation of indigenous matters is a central element of the government's political ideology, which pits the Andean civilisation or 'Andean world' against Western civilisation or the 'western world'. Both are present in the country, but the former is clearly considered the superior of the two. The basis for this superiority is the harmonious relation that Andean civilisations have with nature, which is an intrinsic element of the Andean world,

5 It is very striking that in the 2001 census in Bolivia, 62 per cent of the population declared itself indigenous, and a decade later, in the 2012 census, only 40 per cent of those surveyed declared this status, and this was despite the broad acceptance that Evo Morales had among the indigenous population. Sources: For the 2001 census, see http://bit.ly/1YPfatb; for the 2012 census, see http://bit.ly/1a2BqXD (accessed on 11 November 2016). 
while the Western world is presented as utilitarian and destructive. The following citation explicitly expresses this ideological construction:

In the Western world, man is superior to the earth. It is where the idea that man is separable from the earth is born. This is the reason why land can be sold, transferred, poisoned or killed; they don't care because they are not part of the earth. In the Andean world, man is not superior to the earth; man is part of the earth. He cannot sell the earth, rent it or kill it because the earth is his mother and we are the earth itself.

In the Western world, the future is put forward. Forward and always forward, are science and technology, until the atomic bomb is achieved and the world is destroyed.

In the Andean world, the future is not before us; the future is behind us; the future is in our history, our roots and our identity. A people without history is a people that does not exist.

CHIVI VARGAS, 2010, 25, our transl.

The impact of this pro-indigenous discourse on the population is thought to be high and is surely one of the reasons - along with major redistributive programmes - why, after more than ten years of running the country, Evo Morales remains so popular. It is no minor fact that the indigenous populations, which had been treated symbolically, and in real terms, as inferior throughout colonial and republican history, found a government that sustains, both forcefully and persistently, a discourse that extols the virtues and values of these cultures-in particular their real or imagined harmonious relation with nature - and does so in a context in which it is evident that certain modes of production and consumerism pursued by developed and so-called emerging countries reflect an instrumental relationship with nature that is frequently aggressive and destructive.

Nevertheless, Bolivia, which is part of the globalised world, is not free of contradictions. To maintain its redistributive policies, it needs revenues from extractive exports, mainly gas and minerals, and from monocrop plantations such as soybean, all of which have strong negative impacts on natural resources, global warming and on indigenous populations.

The difficulties surrounding efforts to put the right to create indigenous autonomous territories into practice, as enshrined in the constitution, show the real limits of a political system that, at the end of the day, rides heavily on the back of a centralistic government and a charismatic leader. A meticulous study of the Bolivian situation contends that the national government cannot overcome its fear of the real possibility that indigenous, self-governing 
territories will be formed, constituting a community-based democracy without political parties and with the right to be consulted before natural resources are exploited. While on paper the national government has recognised a broad range of indigenous rights, it has yet (or has chosen not) to communicate an explicit and comprehensible message about the importance of implementing indigenous autonomy to exercise and realise said rights' (Colque, 2015, our transl.). Colque contends that one of the underlying reasons for this situation is that 'the indigenous autonomies contemplated have clashed with economic interests arising from extractive activities. This change embodies the breaking point that has generated the greatest impact on the decline of indigenous autonomies' (Colque, 2015, our transl.).

At the beginning of 2012, the government of Evo Morales experienced one of the greatest challenges to its leadership of the indigenous movement when thousands of people marched to block the construction of the highway between Villa Tunari and San Ignacio de Moxos in the departments of Cochabamba and Beni-a highway that would have cut the Indigenous Territory and the Isiboro-Secure (Territorio Indígena y Parque Nacional Isiboro Sécure, TIPNIS) in half. The government finally ceded to the peasants' demands, issuing a law that declared the territory intangible and explicitly forbidding the construction of the road. At the origins of the conflict was the Bolivian government's need to continue increasing fiscal revenues by exploiting natural resources, specifically gas and minerals. In the words of Miguel Urioste, 'the conflict of TIPNIS is a glaring example of the contradiction between the indigenous-environmentalist discourse (the alternative model to capitalism) and the real option for a developmental-'extractivist' model (model of state capitalism)' (Ortiz Echazu, 2012, 191).

During his campaign for the Ecuadorian presidential elections, Rafael Correa referred to indigenous issues but he did not make them as central as in the discourse of Evo Morales. The United Pachakutik Plurinational Movement, which was involved in the indigenous issue, did nevertheless support Correa in the second round of presidential elections in 2006. This support was short-lived though. Indigenous groups, including CONAIE, one of the country's strongest social organisations, denounced Correa's support to investments in mining and in other megaprojects due to their negative impact on the environment. The environmental issue became the centre of conflict between the government and indigenous populations, which opposed Correa's extractivist policies.

In Peru, indigenous stances have not had significant political influence despite the large indigenous population. On the contrary, Peruvian president Alan Garcia (2006-11) published a celebrated and widely disseminated article 
during his second term that clearly reflected his conception of indigenous and environmental issues. Garcia contended that the country's enormous natural resources cannot be exploited because they are in the hands of peasants and natives that use them inadequately because they are poor and uneducated, and thus these resources should be transferred to investors. The peasant communities that - he said - live in extreme poverty expecting 'the state to provide all the help necessary instead of putting their hills and lands to good economic use' should rent or transfer these lands, 'because if these lands are not productive for them, they would be productive with a high level of investment or knowledge that would be provided by a new buyer. [...] There are idle lands because the owner has no education or resources; thus his property lies dormant. The same land, sold in large lots, will bring technology that community members can also benefit from, but the ideological spider's web [communist, now transformed into environmentalist] of the nineteenth century subsists as an impediment' (Garcia, 2007, our transl.).

Despite Garcia's lack of sensitivity towards indigenous and environmental issues, his government was forced to create the Ministry of the Environment to comply with the commitments inherent in a free trade agreement signed with the United States government. The government that succeeded Garcia's, presided over by Ollanta Humala, passed the Law for the Right to Prior Consultation of Indigenous or Native Peoples in response to the demands of indigenous organisations. This set the stage for ILO Convention 169 to finally be put into practice, years after Peru had signed this agreement in 1994. This law was one of the commitments that the government assumed after negotiating with indigenous organisations in response to 'baguazo', a conflict between police and natives in Bagua who were protesting river contamination due to oil exploitation. The incident ended in a massacre. In the Peruvian case, beyond the authorities' choice of neo-liberalism and their insensitivity to environmental issues and indigenous populations, it was necessary to adopt pro-environmental and pro-indigenous measures due to the international context—in this case the signing of a free trade agreement—and social pressures.

A comparative analysis of the cases of Correa in Ecuador, Morales in Bolivia and the situation in Peru was conducted by Anthony Bebbington, who outlines the great similarities between the first two countries - both of which are aligned with the ideals of 'twenty-first century socialism' and propose moving beyond extractivism - and the extractivist and neo-liberal orientation of successive Peruvian governments. 'Taken together, the politics and economics surrounding extraction in these three countries complicate distinctions between neo-liberalism and post-neoliberalism, raising questions as to what the pre-fix 'post' refers to. If it is supposed to refer to differences in macroeconomic policy, 
then as far as the extractive economy is concerned these differences are not that great. If it merely refers to differences in political discourses and the ways in which nationalism, imperialism and capitalism are talked about, then the difference implied by being 'post' would seem to be more rhetorical that substantive. And if it refers to differences in political style and practice, distinguishing regimes that are brazenly sympathetic to extractive capital from those that are just actually sympathetic, then ironically the 'post'-neoliberal seems the less transparent of the two. To the extent, then, that Bolivia and Ecuador have been sources of inspiration for those who hope for a post-neoliberal agenda, the implication is that much more hard work has to be done to define the substance of this agenda' (Bebbington and Humphreys Bebbington, 2010).

In Colombia, the 'rebirth' of native peoples began at the end of the $1960 \mathrm{~s}$ when the government of Carlos Lleras (1966-70) called on these groups to support the implementation of Law 135 of 1961 on agriculture reform. In alliance with other peasant organisations and unions for agricultural workers, the natives took their mobilisations to departmental capitals and to the country's capital. This was accomplished despite the fact that the road taken to present their claims was laden with internal divisions and considerable loss of life and property; regardless, 'they generated a positive effect in terms of recovering their lands' (Fajardo Montaña, 2014, 104).

\section{5}

Final Notes

Different political options do not always generate significantly different results on core issues. We have seen that beyond alignment with 'twenty-first century socialism' or 'neo-liberalism', the differences in terms of how property concentration is treated are not major, even though the governments of Colombia and Peru are more enthusiastic supporters of investment in large-scale farming for export than are the governments in Ecuador and Bolivia. This also reflects, to a large degree, a response to global processes, such as the increase in the demand for certain agriculture products (fruits, vegetables and feed for cattle) and for biofuels-sectors in which all four countries boast comparative advantages. In this context, all four are in a position to reap foreign exchange and increasing fiscal revenues. The governments of Morales and Correa could not sustain their major social programmes - and their support for large sectors of the population - without these income flows. Large differences exist, in practice, in how each of the four countries treats foreign investments.

Peru and Colombia have been able to execute important redistributive programmes in a context in which high prices for these countries' export 


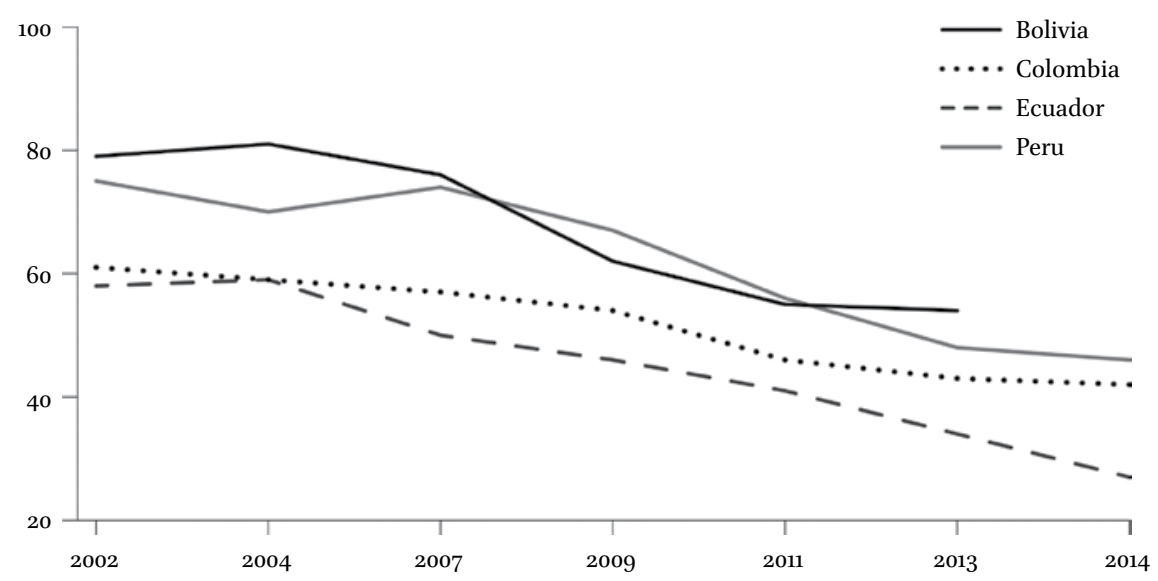

FIGURE 6.1 Evolution of rural poverty in Bolivia, Colombia, Ecuador and Peru (in percentage, 2002-14).

SOURCE: CEPAL (2014b).

products have generated a large pool of fiscal revenues. As is evident from Figure 6.1, rural poverty has fallen significantly in all four countries but the decrease was somewhat more significant in Ecuador and Peru than in Bolivia and Colombia.

In terms of the treatment of indigenous populations, differences may be more symbolic than concrete if we compare the two countries that opt for 'socialism of the 21st century' to the two that choose neo-liberalism. On the one hand, as we have seen above, the decrease in rural poverty that was evident in the four countries also benefited the indigenous population, which resides primarily in rural areas. On the other hand, an interesting indicator of the attention paid by each of the countries' governments to indigenous populations is the evolution of the impact of malnutrition on this sector of society in the countries in question. In all four countries, the gap between chronic (height/ age) and global (weight/age) malnutrition among indigenous children as compared to non-indigenous children is marked, being doubled or almost doubled, in the majority of cases, for the former (Table 6.2).

Yet, this information is static. How does the impact on malnutrition in the indigenous populations in two countries with different political orientations evolve over time?

If we compare the situation in Bolivia and Peru (Table 6.3), we can see that in Peru the decrease (2003-08) was noteworthy, much more so than in Bolivia. Peru's starting point was highly unfavourable compared to that of Bolivia, but in twelve years the country reduced chronic malnutrition to less than half. 
TABLE 6.2 Prevalence (in percentage) of chronic and global malnutrition in children under the age of five

\begin{tabular}{llll}
\hline Country (survey year) & Ethnic status & $\begin{array}{l}\text { Malnutrition } \\
\text { chronic }\end{array}$ & $\begin{array}{l}\text { Malnutrition } \\
\text { global }\end{array}$ \\
\hline Bolivia (2008) & Indigenous & 28.0 & 7.5 \\
& Non-indigenous & 12.4 & 3.6 \\
Colombia (2010) & Indigenous & 22.3 & 8.6 \\
& Non-indigenous & 8.5 & 4.6 \\
& & & \\
Ecuador (2004) & Indigenous & 47.6 & 16.5 \\
& Non-indigenous & 21.5 & 9.3 \\
Peru (2012) & Indigenous & 23.1 & 9.0 \\
& Non-indigenous & 11.2 & 4.5 \\
\hline
\end{tabular}

SOURCE: CEPAL (2014a, 156).

TABLE 6.3 Reduction in chronic malnutrition (in percentage)

\begin{tabular}{llllll}
\hline Survey year & Bolivia & & & Peru* & \\
\cline { 1 - 2 } \cline { 5 - 6 } \cline { 5 - 6 } & Indigenous & Non-indigenous & & Indigenous & $\begin{array}{l}\text { Non- } \\
\text { indigenous }\end{array}$ \\
& & & & \\
\hline 2003 & 31 & 20 & 49 & 22 \\
2008 & 28 & 12 & 23 & 11 \\
\hline
\end{tabular}

* For Peru, 2000 and 2012.

SOURCE: FAO $(2014,141)$.

The economies of the four countries grew during the years studied; thus, reductions in poverty and indigence were to be expected. But, Bolivia and Peru also instituted important redistributive and decentralised policies. These policies apparently had better results in Peru's case, where the reduction in indigence was very significant.

In this chapter, we have attempted to demonstrate that in terms of two issues - the process of land property concentration and the treatment of indigenous matters - the differences between the countries oriented towards 'twenty-first century socialism' (Ecuador and Bolivia) and those aligned with 
neo-liberalism (Peru and Colombia) are not as marked as one might expect if we only examine political discourses.

Even though it is claimed that the economy and politics lato sensu are relatively autonomous spheres, the cases of Bolivia and Ecuador suggest that economic factors may represent considerable barriers to political change. In Bolivia and Ecuador, the governments' autonomy to define policies is limited by economic dependence on international markets and investments. Because these countries depend on revenues that derive, to a large extent, from natural resource exports, they have little room to implement radical sociopolitical change. Governments depend on extractivism to fund social programmes (which redistribute revenues) and to empower subordinate social sectors (redistribution of power). Hence, the sustainability of reformist efforts is strongly dependent on the international context. Variations in international demand and of market prices may seriously affect the local economy and the ability of governments to implement generous social policies.

In addition, the needs of extractive activities may result in public policies that go against the expectations, and deteriorate the living conditions (especially the degradation of the environment), of the social sectors that were intended to be the main beneficiaries of these policies, as illustrated by the case of TIPNIS in Bolivia and the support for mining in Ecuador. A significant proportion of these sectors end up manifesting their dissatisfaction to the governments that they had enthusiastically elected.

By comparison, liberal governments are better able to manage the tensions between their political discourse and economic options. In their discourse, they have to affirm their support to rural and indigenous populations but not as their core priority. Their core priority is economic improvement presented as results of economic growth made possible by neo-liberal measures. Whereas sociopolitical change occupies centre stage in the discourse of 'twenty-first century socialism, economic growth is prioritised in the discourse of governments aligned with neo-liberalism.

Finally, achieving real and sustainable social and political changes is a complex task that cannot be achieved without the restructuring of economies that are heavily dependent on primary activities with little added value, little autonomy, and which are contingent on the international economic situation. Otherwise, the crises in countries that at one time assumed the banner of the cause of real socialism, such as Venezuela; the changes in governments in other nearby countries, such as Argentina and Brazil; the discrediting of the government of Nicaragua; moves to bring Cuba and the United States closer together; and, finally, the fact that the current administrations in Bolivia and Ecuador are about to end and are not subject to re-election, 
could indicate the end not of progressivist and Leftist policies, but of one of their particular variants, in the form of 'twenty-first century socialism' itself.

\section{References}

Acosta, A. (2006) Breve historia económica del Ecuador (Quito: Corporación Editora Nacional).

Amaya Navas, Ó.D., R. Caro Espitia and A.L. Ramírez Nivia (2015) Reflexiones sobre el Incodery la institucionalidad agraria en Colombia. Informe preventivo (Bogotá: Instituto de Estudios del Ministerio Público).

Bebbington, A. and D. Humphreys Bebbington (2010) An Andean Avatar:Post-Neoliberal and Neoliberal Strategies for Promoting Extractive Industries, http://ssrn.com/ab stract $=1684540$ (accessed on 14 September 2016).

Bolivia Rural (2010) Según TIERRA, 40\% de la soya estaría en manos brasileñas (La Paz: Bolivia Rural), http://www.boliviarural.org/noticias/noticias-2010/739-segun -tierra-40-de-la-soya-estaria-en-manos-brasilenas.html (accessed on 11 November 2016).

Central Reserve Bank of Peru (2016) Cuadros anuales históricos, http://www.bcrp.gob .pe/estadisticas/cuadros-anuales-historicos.html (accessed on 14 September 2016).

CEPAL (Comisión Económica para América Latina y el Caribe) (2014a) Los pueblos indígenas en América Latina. Avances en el último decenio y retos pendientes para la garantía de sus derechos. Síntesis (Santiago de Chile: CEPAL), http://repositorio.cepal .org/bitstream/handle/11362/37050/4/S1420783_es.pdf (accessed on 14 September 2016).

CEPAL (Comisión Económica para América Latina y el Caribe) (2014b) Panorama Social de América Latina 2014 (Santiago de Chile: CEPAL), http://www.cepal.org/es/ publicaciones/37626-panorama-social-de-america-latina-2014 (accessed on 11 November 2016).

Chivi Vargas, I.M. (ed.) (2010) Bolivia. Nueva constitución política del Estado. Conceptos elementales para su desarrollo normativo (La Paz: Asamblea Legislativa Plurinacional), http://www.vicepresidencia.gob.bo/IMG/pdf/ncpe_cepd.pdf (accessed on 14 September 2016).

Colque, G. (2015) El punto de quiebre de las autonomías indígenas (La Paz: Fundación Tierra), http://www.ftierra.org/index.php/opinion-y-analisis/619-el-punto-de-quie bre-de-las-autonomias-indigenas (accessed on 14 September 2016).

Dinero (2010) 'La economía que deja Uribe: promesas vs. avances' 28 May, http://www .dinero.com/pais/articulo/la-economia-deja-uribepromesas-vs-avances/96315 (accessed on 14 September 2016). 
Eguren, F. (2004) 'Las políticas agrarias en la última década: una evaluación', in F. Eguren, M.I. Remy y P. Oliart (eds.) Perú: El problema agrario en debate-SEPIA X (Lima: Sepia), pp. 19-78, http://www.sepia.org.pe/facipub/upload/cont/882/cont/ file/20080902070541_02_eguren.pdf (accessed on 14 September 2016).

Eguren, L. (2014) Estudio económico costo-beneficio del apoyo estatal a la gran agricultura (Lima: CEPES).

Fajardo Montaña, D. (2014) 'Colombia: agricultura y capitalismo', in G. Almeyra, L. Concheiro Bórquez, J.M. Mendes Pereira and C.W. Porto-Gonçalves (eds.) Capitalismo: tierra y poder en América Latina (1982-2012), Vol. II (Mexico: Universidad Autónoma Metropolitana-CLACSO), pp. 65-122, http://biblioteca.clacso.edu.ar/ clacso/se/20140820034027/CapitalismoTierrayPoderII.pdf (accessed on 14 September 2016).

FAO (Food and Agriculture Organization of the United Nations) (2014) Panorama de la Seguridad Alimentaria y Nutricional en América Latina y el Caribe 2014 (Santiago de Chile: FAO's Regional Office), http://www.fao.org/3/a-i4018s.pdf (accessed on 14 September 2016).

García, A. (2007) 'El síndrome del perro del hortelano', El Comercio, Lima, 28/10, http:// www.justiciaviva.org.pe/userfiles/26539211-Alan-Garcia-Perez-y-el-perro-del-hor telano.pdf (accessed on 14 September 2016).

Martínez Valle, L. (2014) 'De la hacienda al agronegocio: agricultura y capitalismo en Ecuador' en Capitalismo: tierra y poder en America Latina (1982-2012) (Mexico D.F.: CLASCO), http://biblioteca.clacso.edu.ar/clacso/se/20140820034027/CapitalismoTi errayPoderII.pdf (accessed on 11 November 2016).

Martínez Valle, L. (2012) 'El caso de Ecuador', in F. Soto Baquero and S. Gómez (eds.) Dinámicas del mercado de la tierra en América Latina y el Caribe: concentración y extranjerización (Roma: FAO), pp. 231-252, http://www.fao.org/docrep/019/i2547s/ i2547s.pdf (accessed on 14 September 2016).

Morales, J.A. (2008) La experiencia populista de los años ochenta (La Paz: Instituto de Investigaciones Socioeconómicas, Universidad Católica Boliviana), http://www.iisec.ucb.edu.bo/journal/articulos/1202.pdf (accessed on 14 September 2016).

National Institute for Statistics of Bolivia (2013) Características de Poblacióny Vivienda. Censo Nacional de Población y Vivienda 2012 (La Paz: INE), http://www.ine.gob .bo:8081/censo2012/PDF/resultadosCPV2012.pdf (accessed on 14 September 2016).

OECD (Organisation for Economic Co-operation and Development) (2015) Revisión de la OCDE de las Políticas Agrícolas: Colombia 2015. Evaluación y Recomendaciones de Política, OECD Review of Agricultural Policies Series (Paris: OECD), https://www .oecd.org/countries/colombia/OECD-Review-Agriculture-Colombia-2015-Spanish -Summary.pdf (accessed on 14 September 2016).

Ortiz Echazú, M.V. (ed.) (2012) Marcha indígena por el TIPNIS. La lucha en defensa de los territorios (La Paz: Fundación Tierra), http://www.ftierra.org/index.php/ 
publicacion/libro/56-marcha-indigena-por-el-tipnis-la-lucha-en-defensa-de-losterritorios (accessed on 14 September 2016).

Parada Corrales, J. and W. Baca Mejía (2009) 'Apertura y crecimiento: Una visión de la política económica en Colombia, 1950-2007', Serie Documentos IEEC, 29 (Barranquilla: Universidad del Norte), http://ciruelo.uninorte.edu.co/pdf/docu mentos_ieec/29/Documento_IEEC_29.pdf (accessed on 14 September 2016).

Pineda Hoyos, S. (1996) 'Apertura económica y equidad: Los retos de Colombia en la década de los años noventa', in J.O. Melo González (ed.) Colombia hoy (Bogotá: Biblioteca Virtual Luis Ángel Arango), pp. 6-41, http://www.banrepcultural.org/blaa virtual/historia/colhoy/colo16.htm (accessed on 14 September 2016).

Salinas Abdala, Y. (2012) 'El caso de Colombia', in F. Soto Baquero and S. Gómez (eds.) Dinámicas del mercado de la tierra en América Latina y el Caribe: concentración y extranjerización (Rome: FAO), 179-207, http://www.fao.org/docrep/019/i2547s/i2547s. pdf (accessed on 14 September 2016).

SIPAE (El Sistema de Investigacion sobre la Problematica Agraria en Ecuador), ECOLEX (Corporación de Gestión y Derecho Ambiental) and FEPP (Grupo Social Fondo Ecuatorian Populorum Progressio) (2015) Monitoreo Agrario, 16/12 (Quito: SIPAE, ECOLEX, FEPP), http://www.monitoreodelatierra.com (accessed on 14 September 2016).

Soto Baquero, F. and S. Gómez (eds.) (2014) Reflexiones sobre la concentración y extranjerización de la tierra en América Latina y el Caribe (Rome: FAO), http://www.fao .org/3/a-i3075s.pdf (accessed on 14 September 2016).

Soto Baquero, F. and S. Gómez (eds.) (2012) Dinámicas del mercado de la tierra en América Latina y el Caribe: concentración y extranjerización (Rome: FAO), http:// www.fao.org/docrep/019/i2547s/i2547s.pdf (accessed on 14 September 2016).

UNDP (United Nations Development Programme) (2011) Colombia rural. Razones para la esperanza. Informe Nacional de Desarrollo Humano 2011 (Bogotá: UNDP Colombia), http://planipolis.iiep.unesco.org/upload/Colombia/Colombia_NHDR_2011.pdf (accessed on 14 September 2016).

UNDP (2004) Informe de desarrollo humano de Santa Cruz 2004 (La Paz: UNDP and Plural Editores).

Urioste, M. (2012) 'La Gran Paradoja', in Marcha indigena por el TIPNIS. La lucha en defensa de los territorios (La Paz : Fundación Tierra) pp. 190-191, http://www.ftierra .org $/$ index.php?option $=$ com_mtree\&task $=$ att_download\&link_id $=56 \& c f \_i d=48$ (accessed on 14 September 2016). 